\title{
LITERASI KEUANGAN DAN DAMPAKNYA TERHADAP PERILAKU KEUANGAN MASYARAKAT KOTA MEDAN
}

\author{
Delyana R. Pulungan \\ Fakultas Ekonomi dan Bisnis Universitas Muhammadiyah Sumatera Utara \\ Email: pulunganana28@gmail.com
}

\begin{abstract}
ABSTRAK
Penelitian ini bertujuan untuk mengetahui tingkat literasi keuangan masyarakat Kota Medan. Dan kemudian untuk mengetahui pengaruh literasi keuangan terhadap perilaku keuangan masyarakat Kota Medan. Penelitian ini merupakan penelitian deskriptif kuantitatif yang mengambil populasi Kota Medan sebagai objek penelitian. Sampel diambil dengan teknik random sampling. Data yang diperoleh dari kuesioner terhadap 300 sampel dianalisis dengan metode regresi linier berganda dengan perangkat lunak SPSS versi 20. Hasilnya menunjukkan bahwa tingkat literasi masyarakat Kota Medan mayoritas berada pada tingkat menengah. Kondisi ini masih belum maksimal dalam pengelolaan keuangan karena pengetahuan keuangan masih belum terpelajar sehingga berdampak pada rendahnya pertumbuhan ekonomi keluarga. Kemudian literasi keuangan juga memiliki pengaruh yang signifikan dan positif atau mampu mempengaruhi perilaku keuangan masyarakat di Medan. Jika literasi keuangan terpelajar dengan baik maka perilaku keuangan masyarakat lebih baik, jika tidak literasi keuangan jadi rendah, maka perilaku keuangan masyarakat menjadi sangat buruk.
\end{abstract}

\section{Kata Kunci : Literatur Keuangan dan Perilaku Keuangan}

\section{PENDAHULUAN}

Kemiskinan menjadi masalah dan tantangan dalam pembangunan kota Medan. Kota Medan sebagai salah satu kota terbesar ketiga di Indonesia yang masih memiliki jumlah penduduk miskin yang tidak sedikit. Pertumbuhan kota tidak diimbangi dengan jumlah penduduk yang sejahtera semakin bertambah. Sebaliknya dibalik perkembangan Kota Medan sebagai salah satu kota metropolitan masih banyak penduduk yang berada pada kondisi miskin dan jauh dari kata sejahtera.

Sektor keuangan merupakan salah satu cara yang sangat efektif dalam mengatasi angka kemiskinan di Kota Medan. Sektor keuangan diharapkan akan melibatkan masyarakat berpenghasilan rendah atau tidak tetap untuk menggunakan produk dan layanan perbankan, mendapatkan kemudahan untuk memperoleh modal, memiliki tabungan serta pinjaman modal usaha dengan biaya yang murah, melalukan transfer dana tanpa pihak ketiga yang bersifat tidak resmi. Bahkan mereka juga akan diperkenalkan dengan berbagai bentuk asuransi untuk menjamin keberlangsungan masa dengan dengan harga yang terjangkau dan transparan.

Menurut survey World Bank (2011) masyarakat berpenghasilan rendah masih belum membutuhkan layanan dan produk perbankan diakibatkan beberapa hal yaitu: merasa uang yang dimiliki belum cukup, belum adanya pekerjaan tetap dan masih pengangguran, tidak ada manfaat dengan berhubugan dengan pihak bank, tidak membutuhkan kredit, tidak memiliki jaminan untuk meminjam, tidak memiliki kemampuan untuk menyicil pinjaman, masih ada rasa tidak percaya dan rasa tidak 
nyaman dengan pihak perbankan sebagai pihak kedua yang mengelola uang yang dimiliki, adanya anggapa mahal dalam biaya transaksi, tidak ada pengetahuan yang cukup tentang produk/layanan perbankan. Kondisi ini yang akhirnya menyebabkan masih gagal dalam pencapaian inklusi keuangan pada masyarakat miskin atau berpengahasilan rendah.

Berdasarkan hasil survey Financial Services Authority (FSA) tahun 2013 diketahui bahwa tingkat literasi keuangan Indonesia sangat rendah yaitu 21,84\%. Artinya hanya $21,84 \%$ orang Indonesia yang memahami dengan benar tentang hak, kewajiban, biaya dan resiko, serta manfaat dari produk dan layanan keuangan. Kusuma (2014) menyatakan dalam penelitiannya bahwa tingkat literasi keuangan masyarakat Indonesia jauh lebih rendah dibandingkan negara Singapura dan Malaysia, bahkan masih berada pada level di bawah Thailand. Negara Malaysia, tingkat literasi keuangan masyarakatnya berada pada angka 66\%, Singapura telah mencapai angka 98\%, sedangkan Thailand mencapai angka $73 \%$, sedangkan untuk negara Indonesia sangat disayangkan karena masih mencapi angka $28 \%$. Kondisi tersebut merupakan akibat dari masih banyak masyarakat Indonesia yang belum mengenal jasa keuangan.

Data tersebut memberikan gambaran bahwa tingkat kemiskinan yang belum bisa secara maksimal diatasi berkaitan dengan perilaku keuangan masyarakat Kota Medan yang belum baik dalam mengelola keuangannya akibat masih rendahnya tingkat edukasi keuangan yang diperoleh oleh masyarakat Kota Medan. Oleh karena itu peneliti ingin meneliti bagaimana tingkat literasi keuangan masyarakat Kota Medan dan dampak yang diberikan terhadap perilaku keuangan masyarakat Kota Medan yang diharapkan dapat membantu memperbaiki perekonomian keluarga dan pertumbuhan ekonomi Kota Medan.

\section{LANDASAN TEORITIS}

\section{Literasi Keuangan}

Literasi keuangan adalah pengetahuan mengenai konsep-konsep dasar keuangan, termasuk diantaranya pengetahuan mengenai bunga majemuk, perbedaan nilai nominal dan nilai riil, pengetahuan dasar mengenai diversifikasi risiko, nilai waktu dari uang dan lain-lain (Lusardi et al., 2009)

Ada beberapa faktor yang mempengaruhi literasi keuangan yaitu lingkungan sosial, perilaku orang tua, pendidikan keuangan dan pengalaman individu terhadap keuangan (Shim, et al., 2010). Menurut lembaga Otoritas Jasa Keuangan (2014), dinyatakan bahwa secara defenisi literasi diartikan sebagai kemampuan memahami, sehingga literasi keuangan merupakan kemampuan mengelola dana yang dimiliki agar berkembang dan hidup bisa lebih sejahtera di masa yang akan datang. OJK menyatakan bahwa misi penting dari program literasi keuangan adalah untuk melakukan edukasi dibidang keuangan kepada masyarakat Indonesia agar dapat mengelola keuangan secara cerdas, supaya tingkat pengetahuan yang rendah tentang industri keuangan dapat diatasi, kemudian masyarakat tidak mudah tertipu oleh produk - produk investasi yang menawarkan keuntungan tinggi dalam jangka pendek tanpa mempertimbangkan risikonya.

\section{Perilaku Keuangan}

Perilaku keuangan adalah sikap dan tingkah laku seseorang dalam mengelola keuangannya.Tindakan konsumsi dan menabung digunakan sebagai simbol dari perilaku keuangan seseorang (Hira \& Mugenda, 1999). 
Perilaku keuangan juga menjadi gambaran bagaimana seseorang bersikap ketika dihadapkan dengan keputusan keuangan yang harus diambilnya. Seseorang yang mampu mengambil keputusan dalam mengelola keuangannya tidak akan mengalami kesulitan di masa depan dan memperlihatkan perilaku yang sehat sehingga mampu menentukan skala prioritas tentang apa yang menjadi kebutuhan dan keinginannya (Chinen \& Hideki, 2012).

\section{Hipotesis}

Hipotesis penelitian ini adalah:

H1: Literasi keuangan berpengaruh signifikan terhadap perilaku keuangan masyarakat Kota Medan

H2: Tingkat literasi keuangan masyarakat Kota Medan masih belum berada pada tingkat well literate

\section{Tujuan Penelitian}

Tujuan dari penelitian ini adalah:

a. Untuk mengetahui bagaimana pengaruh literasi keungan terhadap perilaku keuangan masyarakat Kota Medan.

b. Untuk mengetahui bagaimana tingkat literasi keuangan masyarakat Kota Medan

\section{METODE PENELITIAN}

Populasi pada penelitian ini adalah masyarakat Kota Medan yang tersebar pada 21 Kecamatan.Sampel yang dipilih untuk penelitian ini diperoleh dengan metode cluster/area random sampling.Teknik pengambilan sampel nantinya akan ditentukan secara proporsional per kecamatan hingga memenuhi jumlah sampel yang diinginkan yaitu 300 orang responden untuk memenuhi kebutuhan teknik analisis data regresi linier berganda. Analisis data menggunakan bantuan software SPSS versi 20.

Data pada penelitian ini akan diperoleh melalui metode kuesioner dan dokumentasi dari beberapa dokumen yang dinilai sesuai dengan kebutuhan penelitian.

\section{PEMBAHASAN}

Berdasarkan hasil penelitian diketahui bahwa responden penelitian yang mewakili penduduk Kota Medan didominasi oleh penduduk dengan jenis kelamin wanita dan penduduk usia produktif dengan penghasilan yang kecil. Selain itu berdasarkan data BPS Kota Medan (Kota Medan dalam angka 2016) diketahui pertumbuhan ekonomi Kota Medan mengalami penurunan yaitu sebesar 5,74\% dibandingkan tahun lalu sebesar $6,05 \%$.

Hasil penelitian menunjukkan bahwa pria diketagorikan lebih mampu menyeimbangkan kebiasaan konsumtif dengan kebiasaan menabung. Sedangkan untuk jenis kelamin wanita diketahui lebih dikuasai olehkebiasaan konsumtifnya dibandingkan kebiasaan menabungnya sehingga responden wanita dinilai tidak terlalu mempersiapkan masa depannya. Wanita memiliki kebiasaan yang sangat konsumtif dalam memenuhi kebutuhan hidupnya sehari-hari terutama berkaitan dengan pemenuhan gaya hidup. Wanita lebih cenderung rendah tingkat edukasi keuangannya sehingga gagal mengelola keuangan dan mempersiapkan keuangannya di masa depan. Hal ini terlihat dari hasil survey bahwa umumnya wanita lebih sedikit pengetahuannya tentang produk dan layanan keuangan khususnya perbankan. 
Selain itu khusus untuk wanita yang bekerja sebagai ibu rumah tangga lebih mengutamakan kebutuhan sehari-hari sedangkan urusan tabungan atau simpanan masa depan diserahkan kepada para suami sebagai kepala rumah tangga. Mereka beranggapan pendapatan rumah tangganya tidak sesuai dengan kebutuhan hidup sehari-hari yang harus dipenuhi apalagi harus disisihkan untuk kebutuhan masa depan. Sehingga untuk kebutuhan mendesak dan tibat-tiba di masa depan mereka mengandalkan hutang untuk mengatasi persoalan. Selain itu masih ada wanita yang lebih senang menyimpan uang di rumah khususnya yang berperan sebagai ibu rumah tangga dibandingkan harus menyimpan ke bank dengan alasan lokasi bank yang dituju terlalu jauh, urusan administrasi yang panjang dan sulit serta alasan klise seperti antrian yang panjang.

Kondisi yang berbeda terjadi untuk responden pria.Ada beberapa yang bersifat bersifat konsumtif dalam pemenuhan kebutuhan hidup sehari-hari atau untuk kebutuhan gaya hidup, tetapi masih lebih banyak yang menyadari kebutuhan untuk menabung atau memiliki investasi demi keselamatan masa depan. Responden pria menyatakan lebih senang mengalokasikan dana untuk investasi pada beberapa barang yang ada nilai investasinya seperti perhiasan emas, property dan lain-lain.

Selain itu diketahuimelalui hasil survey kuesioner bahwa pria diketahui mendominasi dalam hal investasi atau menabung menggunakan layanan perbankan dibandingkan perempuan yang diketahui masih ada yang lebih senang dan merasa nyaman jika menyimpan uangnya di rumah.

Hasil penelitian ini sesuai dengan penelitian yang dilakukan oleh Agnew (2015) yang menyatakan bahwa ditemukan hasil mayoritas murid laki-laki lebih baik pemahamannya tentang keuangan.Selain itu juga ditemukan bahwa murid laki-laki lebih sering menerima edukasi tentang keuangan dari keluarganya dibandingkan murid perempuan yang jarang melakukan diskusi tentang keuangan dengan keluarganya.

Kemudian hasil penelitian ini menunjukkan bahwa kelompok masyarakat yang memiliki status sosial ekonomi baik sudah memiliki literasi keuangan yang baik. Artinya mereka memahami bagaimana mempersiapkan masa depan dengan cara menabung atau berinvestasi Kelompok masyarakat ini bisa membagi kebutuhan konsumtifnya dengan kebutuhan investasi atau menabungnya.

Tetapi berbeda dengan kelompok status sosial ekonomi yang rendah umumnya memiliki literasi keuangan yang tidak baik.Kebutuhan hidup mereka sehari-hari lebih banyak untuk dipenuhi sehingga membuat mereka menganggap tidak terlalu penting atau tidak terlalu perduli untuk menyisihkan sebagian pendapatan mereka dengan menabung atau berinvestasi.Dan mengandalkan hutang jika ada kebutuhan mendesak dan penting di masa depan.

Hasil penelitian ini didukung oleh penelitian yang dilakukan oleh Agnew(2015) yaitulatar belakang keluarga dengan status sosial ekonomi yang baik sudah melakukan edukasi keuangan kepada anggota keluarganya khususnya anak-anaksejak usia dini dibandingkan oleh keluarga dengan status sosial ekonomi yang rendah. Sehingga masyarakat ekonomi rendah memiliki anak-anak yang tingkat pengetahuannya tentang uang lebih rendah, sulit untuk diajarkan betapa pentingnya menabung dibandingkan anak-anak yang berasal dari masyarakat dengan tingkat ekonomi yang baik.

Hasil penelitian ini didukung oleh penelitian yang dilakukan oleh Agnew (2015) yang menyatakan bahwa responden yang berjenis kelamin dan status sosial ekonomi keluarga berdampak terhadap literasi keuangan individual.Pria dan status sosial ekonomi yang baik dinilai lebih baik dalam pemahaman atau edukasi keuangannya.

Kemudian melalui hasil survey diketahui bahwa rata-rata responden menjawab 
pertanyaan seputar tentang produk dan jasa keuangan berada pada level $65 \%$ artinya masih berada pada tingkat medium.Kondisi ini menunjukkan mayoritas responden penelitian belum sepenuhnya memiliki literasi keuangan atau pengetahuan yang baik tentang produk dan jasa keuangan sehingga perilaku keuangan yang mendominasi kehidupan dan aktivitas ekonominya sehari-hari masih bersifat tradisional dan sederhana.

Selain itu masih banyak responden yang belum sepenuhnya percaya dengan produk dan jasa keuangan yang ditawarkan oleh beberapa lembaga keuangan yang disediakan oleh negara seperti perbankan karena adanya anggapan biaya yang mahal, kecanggihan teknologi yang dianggap bukan untuk masyarakat miskin, proses dan administrasi yang lama.

Table 1. Correlation Between Financial Literacy and Financial Behavior

\begin{tabular}{lrr} 
Variabel & Koefisien & Signifikansi \\
\hline (Konstanta) & 6,709 &, 000 \\
\hline Financial &, 535 &, 008 \\
Literacy & & \\
\hline \multicolumn{1}{c}{ Siumber }
\end{tabular}

Sumber: Hasil Pengolahan Data (2017)

Data pada tabel 1 menunjukkan bahwa literasi keuangan memiliki pengaruh yang positif dan signifikan terhadap perilaku keuangan masyarakat Kota Medan dengan nilai probability $(0,008)$ dan besarnya pegaruh yang diberikan adalah $67,09 \%$. Artinya literasi keuangan yang semakin baik akan memiliki dampak yang kuat dan nyata terhadap perilaku keuangan masyarakat juga semakin baik dalam mengelola keuangannya sehingga dapat memperbaiki kehidupan ekonomi masyarakat dan juga berdampak pada peningkatan pertumbuhan ekonomi Kota Medan.

Sebaliknya jika literasi keuangan masyarakat Kota Medan tidak baik maka akan memberikan pengaruh yang tidak baik terhadap perilaku keuangan masyarakat Kota Medan dalam mengelola keuangannya di mana masyarakat akan tidak mampu mempersiapkan masa depannya dengan baik, bergantung pada hutang dan menggunakan pihak ketiga yang tidak resmi dan tidak aman dalam melakukan transaksi keuangannya. Kondisi ini yang akan meningkatkan angka kemiskinan dan berdampak pada rendahnya angka pertumbuhan ekonomi Kota Medan.

Secara keseluruhan hasil penelitian ini menunjukkan bahwa literasi keuangan masyarakat Kota Medan masih cukup rendah karena mayoritas masyarakatnya masih berada di bawah garis kemiskinan.Masih terlihat dan terasa perbedaan status sosial yang terjadi di masyarakat Kota Medan.Terlihat dengan jelas masyarakat yang baik pengetahuan keuangan dengan masyarakat yang tidak baik pengetahuan keuangannya.

Masyarakat ekonomi rendah masih belum terlalu penting untuk mengelola keuangannya dengan baik.Tercermin dari perilaku sehari-hari yang masih percaya dengan pihak-pihak ketiga yang menawarkan jasa atau produk keuangan yang belum terjamin keamanannya. Sehingga masih banyak yang menggunakan rentenir, tengkulak,bahkan investasi bodong untuk memenuhi kebutuhan aktivitas ekonominya sehari-hari.

Hasil penelitian ini didukung oleh penelitian yang dilakukan oleh Chinen dan Endo (2010) yang menyatakan bahwa individu yang memiliki kemampuan untuk membuat keputusan yang benar tentang keuangan maka tidak akan memiliki masalah keuangan di masa depan dan hal itu membuktikan perilaku keuangan yang sehat dan 
mampu menentukan skala prioritas kebutuhan bukan keinginan. Hilgert dan Hogart (2013) juga mendukung hasil penelitian ini karena penelitian mereka menyebutkan bahwa perilaku keuangan yang sehat ditunjukkan oleh kegiatan perencanaa, pengelolaan serta pengendalian seseorang terhadap keuangan pribadinya. Sehingga sikap seseorang dikatakan baik atau tidak terhadap pengelolaan keuangannya berkaitan dengan kemampuan dan pengetahuan seseorang tersebut akan konsep-konsep keuangan yang disebut dengan literasi keuangan.

\section{KESIMPULAN}

Literasi keuangan berpengaruh positif signifikan terhadap perilaku keuangan masyarakat Kota Medan. Tingkat pengetahuan dan kemampuan dalam mengelola keuangan pribadi atau keluarga yang baik akan mampu mengarahkan seseorang untuk mengelola keuangan dengan baik, sehingga tidak akan memiliki masalah keuangan di masa depan dan dikatakan sudah memiliki kemampuan menentukan skala prioritas kebutuhan bukan keinginan dalam memanfaatkan uang yang dimiliki.

Tingkat literasi keuangan masyarakat Kota Medan berada pada level medium artinya belum sepenuhnya well literate. Masyarakat Kota Medan masih didominasi oleh penduduk yang memiliki tingkat edukasi keuangan yang belum sepenuhnya baik sehingga berdampak pada rendahnya tingkat pertumbuhan ekonomi keluarga dan juga berdampak pada rendahnya tingkat pertumbuhan ekonomi Kota Medan.

\section{DAFTAR PUSTAKA}

Agnew, Stephen and Trudi Cameron-Agnew. 2015. The Influence of Gender and Household Culture on Financial Literacy Knowledge; Attitudes and Behaviour. Journal of Financial Management, Markets and Institutions (ISSN 2282-717X)

Chinen, Kenichiro \& Hideki Endo. 2012. Effect of Attitude and Bacground on Personal Finance Ability: A Student Survey in the United State. International Journal of Management. (29).1: 33-45

Hilgert, M.A \& Hogart M. 2003. Household Financial Management: The Connectionbetween Knowledge and Behavior. Federal Reserve Bulletin July 2003

K. Chinen, E. Hideki. Effect of Attitude and Background on Personal Finance Ability: A Student Survey in the United State, 29(1)(2012) 33-45.

Kusuma, Dewi Rachmat. 2014. Melek Keuangan Masyarakat Indonesia Masih di Bawah Singapura dan Malaysia. (Online). http://finance.detik.com [13 Agustus 2015].

Lusardi, A, Mitchel,O S, \& Curto,V,. 2009. Financial Literacy Among the Young: Evidence and Implications for Consumer Policy. In Pension Research Working Paper.Pension Research Council, University of Pensylvania.

[OJK] Otoritas Jasa Keuangan. 2014. Brosur Strategi Nasional Literasi Keuangan Indonesia. Jakarta.

S. Shim, S., B.L. Barber, N.A. Card, J-J. Xiao, J. Serido. Financial Socializaqtion of First-year College Students: The Roles of Parents, Work, and Education, Journal of Youth Adolescence, 39((2010) 1457-1470.

T. K. Hira, O. M. Mugenda.The relationship between self-worth and financial beliefs, behavior, and satisfaction. Journal of Family and consumer Sciences, 91(4)(1999) $76-82$ 